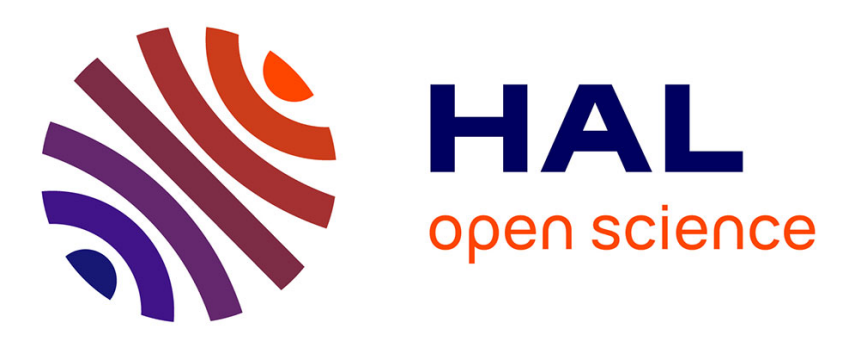

\title{
HM-Based SMVC with Adaptive Feedforward Controller Applied to DC-DC Converter
}

Rihab Hamdi, Amel Hadri Hamida, Ouafae Bennis, Fatima Babaa

\section{To cite this version:}

Rihab Hamdi, Amel Hadri Hamida, Ouafae Bennis, Fatima Babaa. HM-Based SMVC with Adaptive Feedforward Controller Applied to DC-DC Converter. IEEE 4TH INTERNATIONAL CONFERENCE ON ELECTRICAL AND INFORMATION TECHNOLOGIES, Mar 2020, RABAT, Morocco. hal-02455406

\author{
HAL Id: hal-02455406 \\ https://hal.science/hal-02455406
}

Submitted on 26 Jan 2020

HAL is a multi-disciplinary open access archive for the deposit and dissemination of scientific research documents, whether they are published or not. The documents may come from teaching and research institutions in France or abroad, or from public or private research centers.
L'archive ouverte pluridisciplinaire HAL, est destinée au dépôt et à la diffusion de documents scientifiques de niveau recherche, publiés ou non, émanant des établissements d'enseignement et de recherche français ou étrangers, des laboratoires publics ou privés. 


\section{HM-Based SMVC with Adaptive Feedforward Controller Applied to DC-DC Converter}

\author{
Rihab Hamdi \\ LMSE Laboratory, Department of \\ Electrical Engineering \\ University of Biskra \\ Biskra, Algeria \\ rihab.hamdi2012@gmail.com
}

\author{
Amel Hadri Hamida \\ LMSE Laboratory, Department of \\ Electrical Engineering \\ University of Biskra \\ Biskra, Algeria \\ am_hadri@yahoo.fr \\ Fatima Babaa \\ LEC Laboratory, Department of \\ Electrical Engineering \\ Constantine1 University \\ Constantine, Algeria \\ babaa.fatima@yahoo.fr
}

\author{
Ouafae Bennis \\ PRISME Institute, University of \\ Orléans, 21 rue Loigny La Bataille, \\ 28000 Chartres \\ Orléans, France \\ ouafae.bennis@univ.orleans.fr
}

\begin{abstract}
This paper aims to provide a comprehensive study of sliding mode controller (SMC) performance for closedloop voltage control of DC-DC three-cells buck converter based on hysteresis modulation (HM) where an adaptive feedforward technique is adopted. To fix the switching frequency, the approach is to incorporate a feedforward adaptive scheme which is effectively a variant of SM control. Further, the use of an adaptive feedforward control that makes the hysteresis band variable in the hysteresis modulator of the SM controller to restrict the switching frequency variation feeding parameters uncertainties and loads disturbance, in order to overcome the design constraints and to mitigate the undesired transient response. The results obtained under load change, input change and reference change clearly demonstrates a great dynamic response of the proposed technique, as well as provide stability in any operating conditions, the effectiveness is fast with a smooth tracking of the desired output voltage. Simulations studies in MATLAB/Simulink environment have been performed to verify the concept.
\end{abstract}

Keywords-Sliding Mode Control, Adaptive control, DC-DC converter, Parallel Multi-cells converter, Robustness

\section{INTRODUCTION}

In the field of strong currents with high switching frequencies, while automating technological processes, there is a tendency to develop and use new structures based on the combination of components. Among them, we find the parallel multicellular converters that have been receiving increased attention recently. The various control methodologies currently being considered to achieve a constant output voltage and have been found to have potential applications in DC-DC converters that require very high performance in dynamical response [1] - [3].

The various control methodologies currently being considered to achieve a constant output voltage and have been found to have potential applications in DC-DC converters that require very high performance in dynamical response. Theoretically, to achieve a sliding mode control operation in a perfect way, the system should be operated at a high switching frequency so that the controlled variables can follow closely the reference to achieve the desired dynamic response and steady-state operation. Along with this requirement, however, the feasibility of applying SM control to DC-DC converters is questioned [4], [5]. This is because extreme high-speed switching in DC-DC converters leads to an excessive switching loss, inductor and transformer core losses, and "electromagnetic interference" noise issues. Hence, their switching frequencies must be constricted within a specifical range in order to make the SM control applicable to DC-DC converters.

Therefore, the design of such converters is a challenge for electrical engineers due to the use requirements and the inherent nonlinear nature. All the converters have few requirements like high density which leads to a smaller size, high efficiency which leads to low losses and robust to any changes in the input or output [6], [7]. For surpassing the problem of high frequency, a new class of power converter appeared: the multicellular converter. The multicellular conversion has inherent advantages that make it an increasingly attractive solution that can be considered for any application. It provides more degrees of freedom to the designer, but it also makes the design more complicated since many options can be considered [8] - [12]. The HM strategy can be applied to develop fixed-frequency SM controllers and the technique of state-space averaging was incorporated into the controller's modeling [13], [14]. In turn, as known, the limitation of the conventional HM based sliding mode controller consists of the significant variation of the switching frequency in the presence of disturbances and parametric uncertainties. This disadvantage leads to overestimating the properties of the filters in the converter and to impropriate modifications of the regulation. Hence, it is recommended to operate the converter at a constant switching frequency [15].

To surpass this problem, we propose an adaptive controller with a feedforward technique in intent to overcome the imperfect feedback loop that causes a small steady-state error in the output voltage [16]-[21]. Unlike the feedback technique, that needs a perception of a past situation, the feedforward technique is illustrated in the formulation of commands to propose solutions for the future. In other words, it consists of the anticipation of the action that follows.

The major contribution of this work is to present thorough a discussion of the problem of switching frequency variation and the effectiveness of the adaptive solution in alleviating the problem through a close examination of the basic structure.

The remainder of the paper is organized into 5 sections: 
Section II outlines the system's topology and operating principle. Section III discusses the control scheme and the operating mechanism of the variable hysteresis band. Simulation results are presented and discussed in Section IV; Section V concludes the paper.

\section{Parallel Multi-Cell Converter}

DC-DC converters constitute a particular class of nonlinear, time-varying systems. The paralleling of cell switching is accomplished by directly connecting the cells to the voltage source. The multicellular converter is based on the combination of elementary cells of commutation. This signal is equal to 1 when the cell upper switch is conducting and equal to 0 when the lower complementary switch is conducting. These cells are associated in parallel with an RL load and separated by capacitors application to a three-cells buck converter. Fig. 1 depicts a basic topology of the buck converter, in which $\mathrm{V}_{\mathrm{i}}$ is the input DC voltage; $\mathrm{L}$ is the filter inductor; $\mathrm{C}$ is the capacitor; $\mathrm{R}$ is the load. Then the system dynamics of the buck converter can be expressed as:

$$
\begin{aligned}
& L \frac{d i_{L}}{d t}=-i_{L}-V_{\text {out }}+u . V_{i} \\
& C \frac{d v_{\text {out }}}{d t}=i_{L}+\frac{V_{\text {out }}}{R}
\end{aligned}
$$

Where $i_{L}$ is the inductor current, $V_{\text {out }}$ is the output DC voltage, $u$ is the control input.

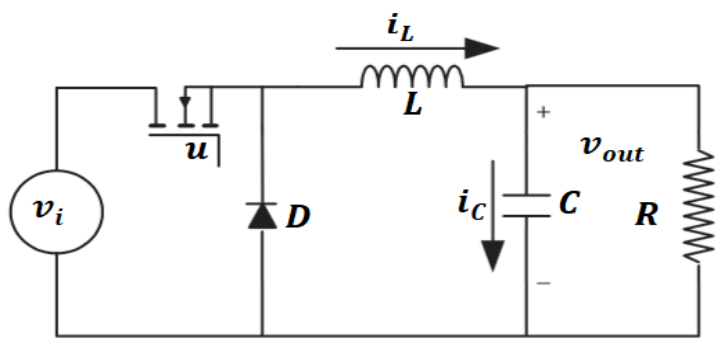

Fig. 1. Basic topology of the Buck converter.

The multicellular converter consists of phases, where each cell contains two complementary power electronics components and it is controlled by a binary switch. A 3-phase converter feeds a single load assumed to be resistive. The considered multicellular buck converter is a second-order converter, with Single Input Single Output (SISO) structure, where, the cells are associated in parallel with $\mathrm{R}$ load, realized in MATLAB/SIMULINK.

Fig. 2 illustrates the configuration adopted of the threecell step-down DC-DC converter associated with parallel realized in the MATLAB/Simulink environment.

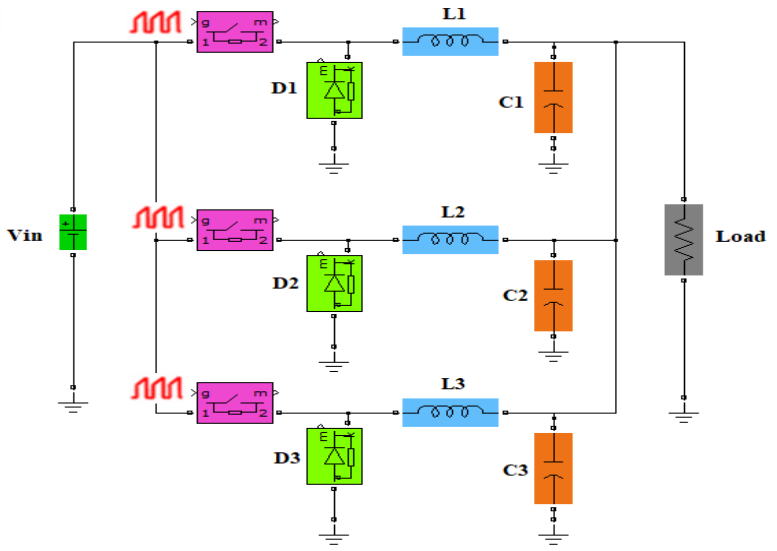

Fig. 2. Three-cell Buck converter associated in parallel.

\section{The Operating MECHANISM}

The proposed controller-based SM control via hysteresis modulation is applied to buck type DC/DC converter.

The mathematical model of the buck converter is

$$
\begin{gathered}
x_{1}=V_{\text {ref }}-V_{\text {out }} \\
x_{2}=\dot{x}_{1}=-\frac{d V_{\text {out }}}{d t}=\frac{1}{C}\left(\frac{V_{\text {out }}}{R}-\int \frac{u V_{i}-V_{\text {out }}}{L} d t\right)
\end{gathered}
$$

For the system modeling and state-space descriptions required for the design of SM voltage control for buck converter operating in CCM, the state-space may be expressed in the following form:

$$
\left[\begin{array}{l}
\dot{x}_{1} \\
\dot{x}_{2}
\end{array}\right]=\left[\begin{array}{cc}
0 & 1 \\
-\frac{1}{L C} & -\frac{1}{R C}
\end{array}\right]\left[\begin{array}{l}
x_{1} \\
x_{2}
\end{array}\right]+\left[\begin{array}{c}
0 \\
-\frac{V_{i}}{L C}
\end{array}\right] u+\left[\begin{array}{c}
0 \\
\frac{V_{r e f}}{L C}
\end{array}\right]
$$

For an SM voltage controller, the switching function $u$ can be determined from the control parameters $x_{1}$ and $x_{2}$ using the state trajectory computation:

$$
S=\alpha x_{1}+x_{2}=J x
$$

Where : $\left\{\begin{array}{c}J=[\alpha, 1] \\ x=\left[x_{1}, x_{2}\right]^{T}\end{array}\right.$

This forms the basis for the control law :

$$
u=\left\{\begin{array}{cc}
1={ }^{\prime} O N^{\prime} & \text { When } S \succ k \\
0=^{\prime} O F F^{\prime} & \text { When } S \prec k
\end{array}\right.
$$

To determine asymptotic stability the existence condition, which is derived from Lyapunov's second method, must be obeyed :

$\lim _{S \rightarrow 0} S . \dot{S} \prec 0$

Thus, the condition for SM control to exist is

$$
\dot{S}= \begin{cases}J \dot{x} \prec 0 & \text { for } 0 \prec S \prec \xi \\ J \dot{x} \succ 0 & \text { for }-\xi \prec S \prec 0\end{cases}
$$

where $\xi$ is an arbitrarily small positive quantity

Substituting (3) and (5), we find :

$S=\frac{1}{R}\left(V_{\text {ref }}-V_{\text {out }}\right)-i_{C}$ 
Also, the width of the hysteresis band $\kappa$ is a fixed parameter that can be determined using :

$$
k=\frac{V_{r e f}\left(1-\frac{V_{r e f}}{V_{i}}\right)}{2 f w L}
$$

with $f_{w}, V_{\text {ref }}$, and $V_{i}$ representing the steady-state switching frequency, the desired output voltage, and the input voltage, respectively.

The above equation is valid only if the sliding coefficient is set as :

$$
\alpha=\frac{1}{R C}
$$

Under this configuration, the conditions for SM control to exist are :

$$
\begin{gathered}
\lambda_{1}=\left(\alpha C-\frac{1}{R}\right) x_{2}-\frac{1}{L} x_{1}+\frac{V_{r e f}-V_{i}}{L} \prec 0 \\
\lambda_{2}=\left(\alpha C-\frac{1}{R}\right) x_{2}-\frac{1}{L} x_{1}+\frac{V_{r e f}}{L} \succ 0
\end{gathered}
$$

The proposed controller-based sliding mode control via hysteresis modulation is applied to buck type DC-DC converter. To keep the switching frequency fixed against line variation, an adaptive feedforward control scheme that varies the hysteresis band in the hysteresis modulator of the SM controller in the event of any change of the line input voltage must be introduced. Fig. 3 shows the basic structure of the adaptive feedforward SMVC buck converter.

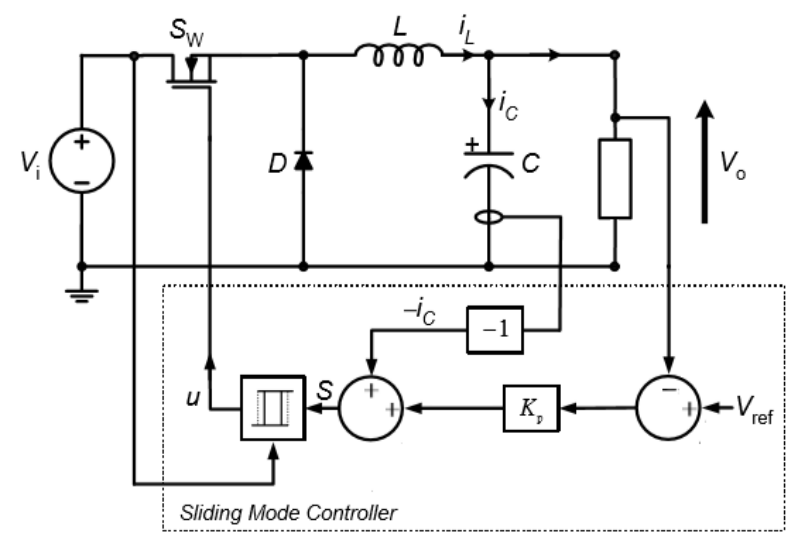

Fig. 3. The basic structure of an adaptive feedforward SMVC buck converter.

The operation of the adaptive feedforward variable hysteresis band and the variable hysteresis band scheme are illustrated in Fig. 4 and Fig. 5, which shows the trajectory of $S$ of the steady-state operation for one switching cycle. Here, the terms $S_{\text {off(min) }}$ and $S_{\text {on(min) }}$ represent the trajectory of $S$ when the input voltage is minimum for, respectively, the turn-off period $T_{\text {off(min) }}$ and turn-on period $T_{\text {on(min) }}$. Similarly, $S_{\text {off(max) }}$ and $S_{\text {on(max) }}$ represent the trajectory of $S$ when the input voltage is maximum, for respectively the turn-off period $T_{o f f(\max )}$ and turn-on period $T_{\text {on(max) }}$. Also, $\kappa_{\min }$ and $\kappa_{\max }$ represent the required width of the hysteresis band for maintaining the same switching frequency at the minimum and the maximum input voltage.

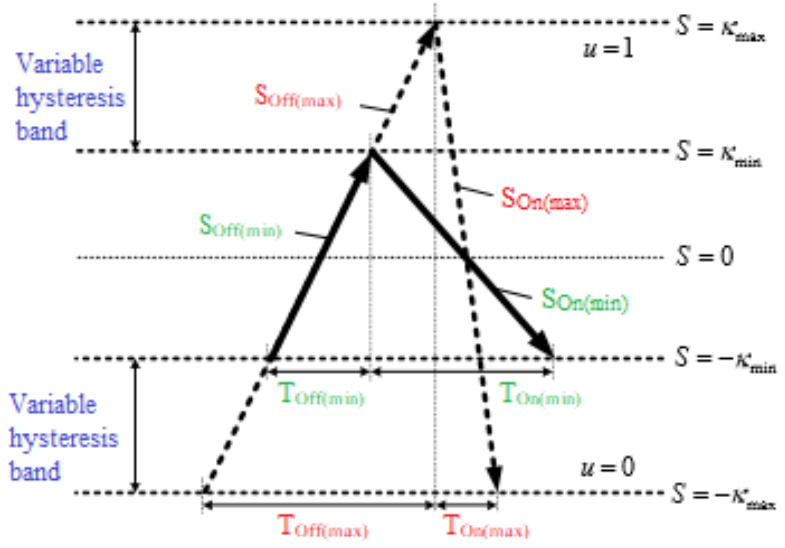

Fig. 4. The operating mechanism of the adaptive feedforward variable hysteresis band.

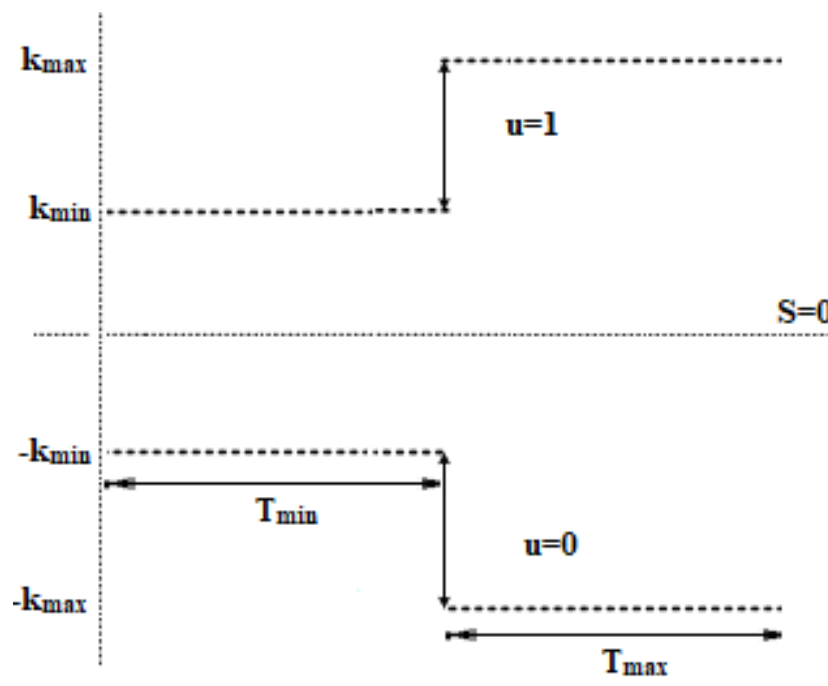

Fig. 5. The variable hysteresis band scheme.

\section{Simulation Results}

In order to illustrate the performance of the proposed control, we considered a three-cell converter connected to an $\mathrm{R}$ load. The performances of the developed techniques based SM control were verified through simulation using MATLAB software.

Table I show the specifications of the buck converter used in the MATLAB simulation.

TABLE I. SPECIFICATION OF THE CONVERTER

\begin{tabular}{|l|l|c|c|}
\hline \multirow{4}{*}{$\begin{array}{c}\text { Converter } \\
\text { Type }\end{array}$} & \multicolumn{3}{|c|}{ The Properties Of Each Cell } \\
\cline { 2 - 4 } & Description & Parameter & Nominal value \\
\hline \multirow{4}{*}{$\begin{array}{l}\text { Parallel } \\
\text { Three-cell } \\
\text { Buck } \\
\text { Converter }\end{array}$} & Capacitance & $\mathrm{V}_{\mathrm{i}}$ & $24 \mathrm{~V}$ \\
\cline { 2 - 4 } & Resistance & $\mathrm{C}$ & $6 \mathrm{e}-6 \mathrm{~F}$ \\
\cline { 2 - 4 } & Inductance & $\mathrm{R}$ & $12 \Omega$ \\
\cline { 2 - 4 } & Switching frequency & $f w$ & $0.1 \mathrm{H}$ \\
\cline { 2 - 4 } & Desired output voltage & $\mathrm{V}_{\text {ref }}$ & $12 \mathrm{VHz}$ \\
\hline
\end{tabular}

To test the performance of the proposed controller, a comprehensive simulation under sequence step load change 
(variation of $50 \%$ ) with constant input voltage was tested. The reference output voltage was set to $12 \mathrm{~V}$, the load resistance changes from $12 \Omega$ to $6 \Omega$. The situation where the load changes suddenly from one value of load resistance to another is considered. This particularly interesting because it is a typical problem for power electronics, where the power supply is supposed to compensate quickly for the load variation.

Robustness test versus the load resistance variation is illustrated by Fig. 6 and Fig. 7, showing that the state variables exhibit a transient but the output voltage converges to the desired reference. According to these results, it can be noticed that the performances of the proposed control for load variation are satisfactory.

Then, the multicellular converter is initially powered by an input voltage $V_{i}=24 \mathrm{~V}$ which varies at instant $t=0.4 \mathrm{~s}$ to reach $50 \mathrm{~V}$, to test the robustness of the developed controller, the disturbance is assigned to the level of the supply voltage.

Fig. 8 and Fig. 9 summarizes the results of this test. There is a very brief transient that lasts a few $m s$ followed by a steady-state giving voltage values $V_{\text {out }}$ proportional to the new value of $V_{i}$.

Finally, the robustness test versus the power reference value changes is illustrated in Fig. 10 and Fig. 11. Indeed, at $\mathrm{t}=0.4 \mathrm{~s}, V_{\text {ref }}$ is slightly changed from $12 \mathrm{~V}$ to $14 \mathrm{~V}$.

According to these results, it can be noticed that the control strategy objective is fulfilled and the performances are satisfactory.
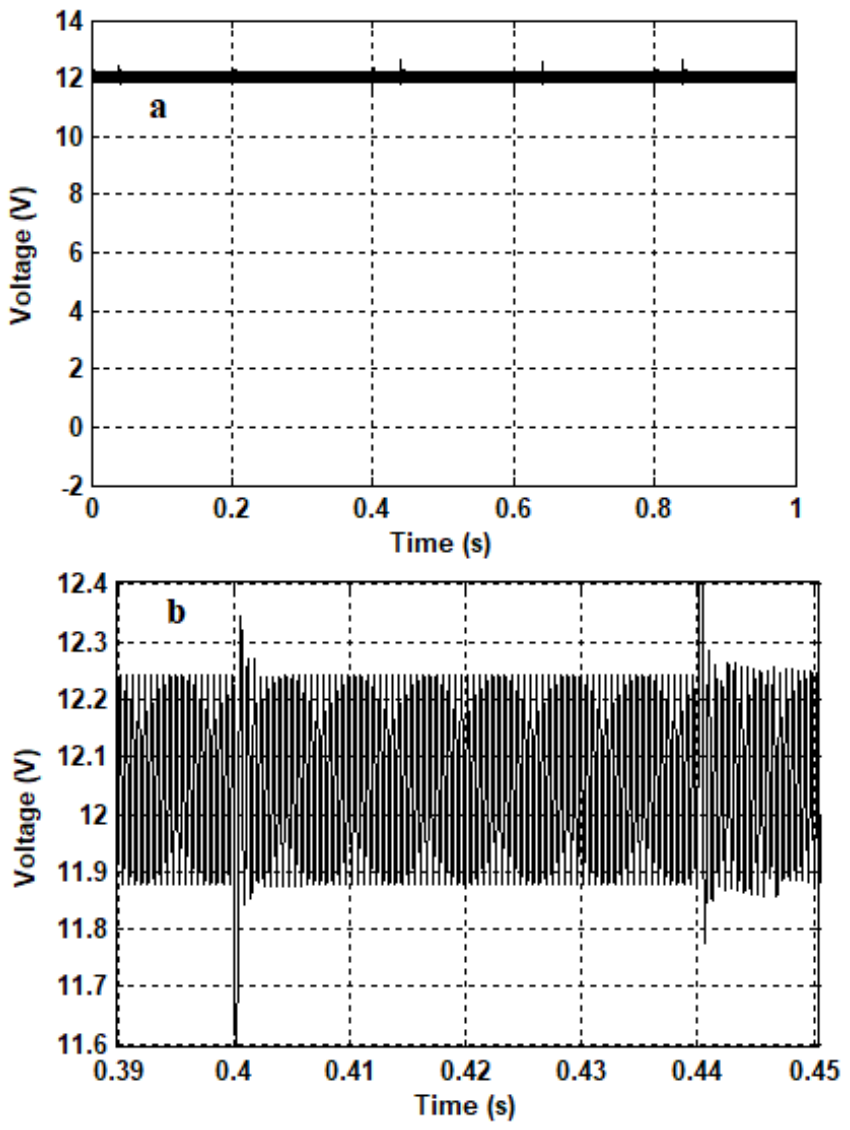

Fig. 6. (a) Simulation results of the Output voltage response with an output load variation. (b) Zoom in.
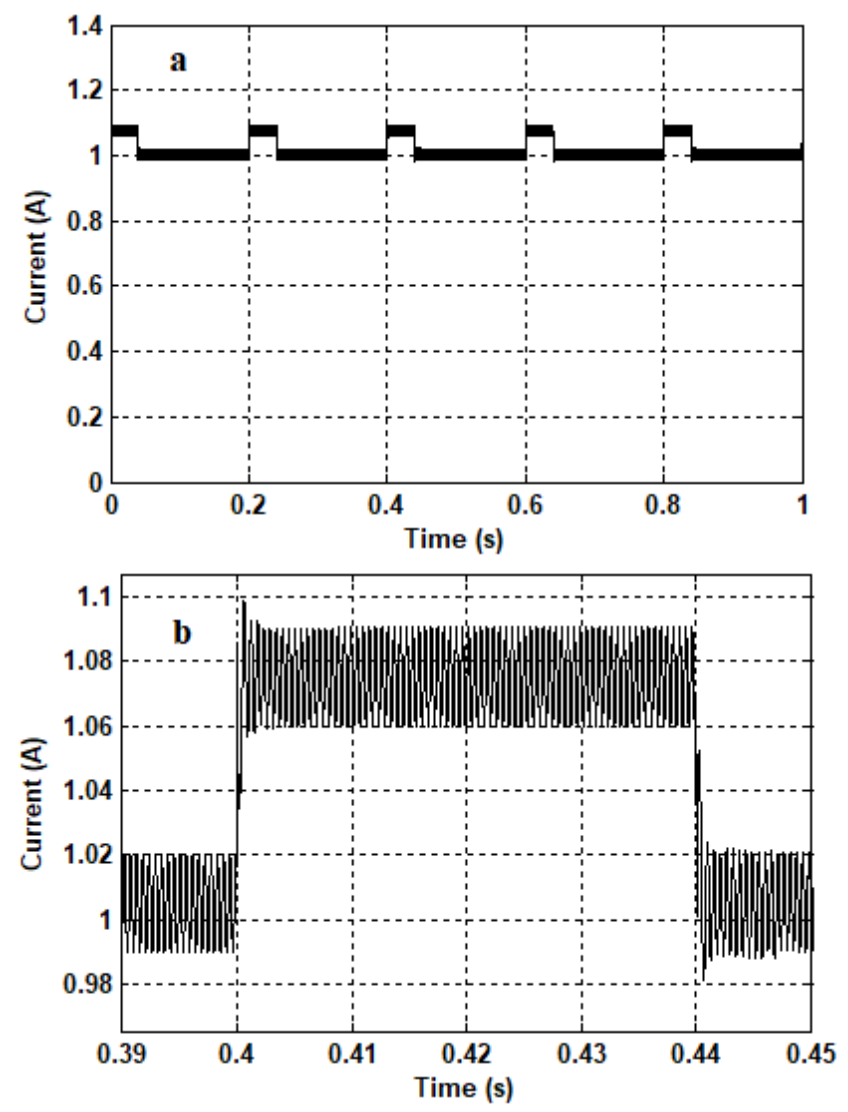

Fig. 7. (a) Simulation results of the Output load current response with an output load variation. (b) Zoom in.
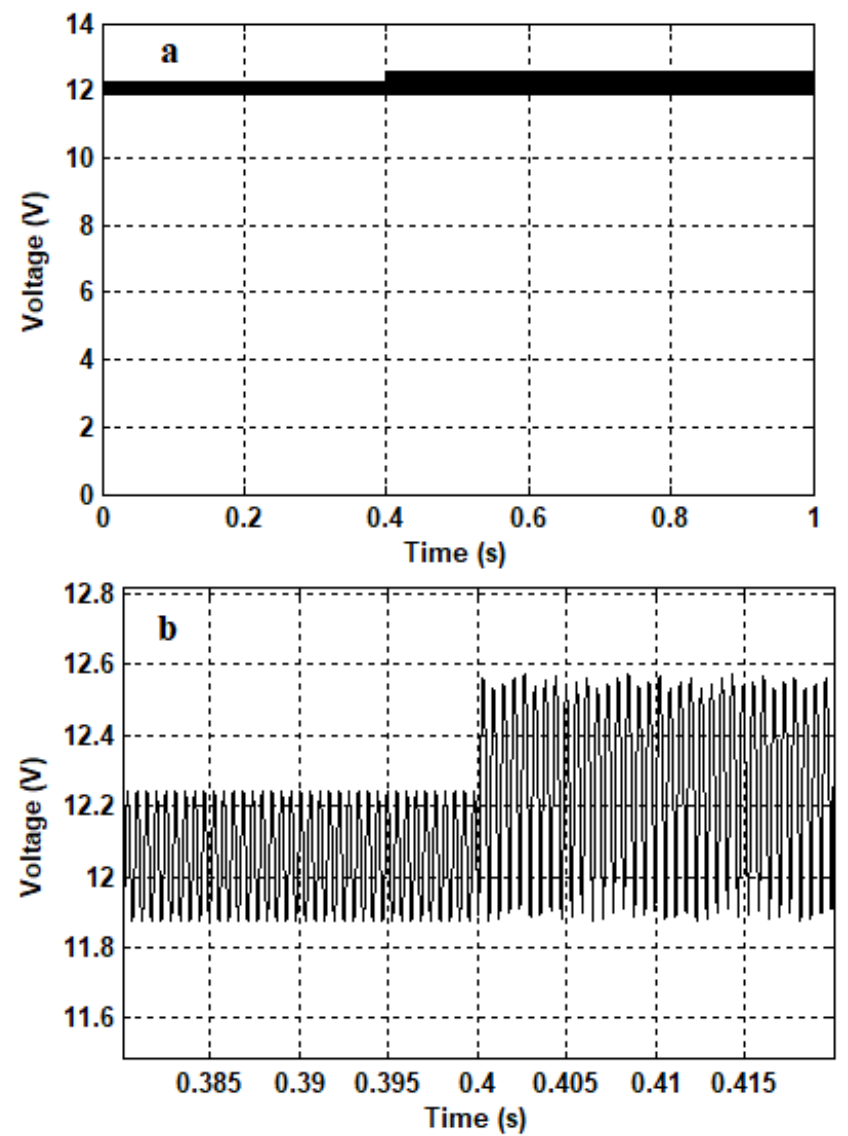

Fig. 8. (a) Simulation results of the Output voltage response with an input voltage variation. (b) Zoom in. 

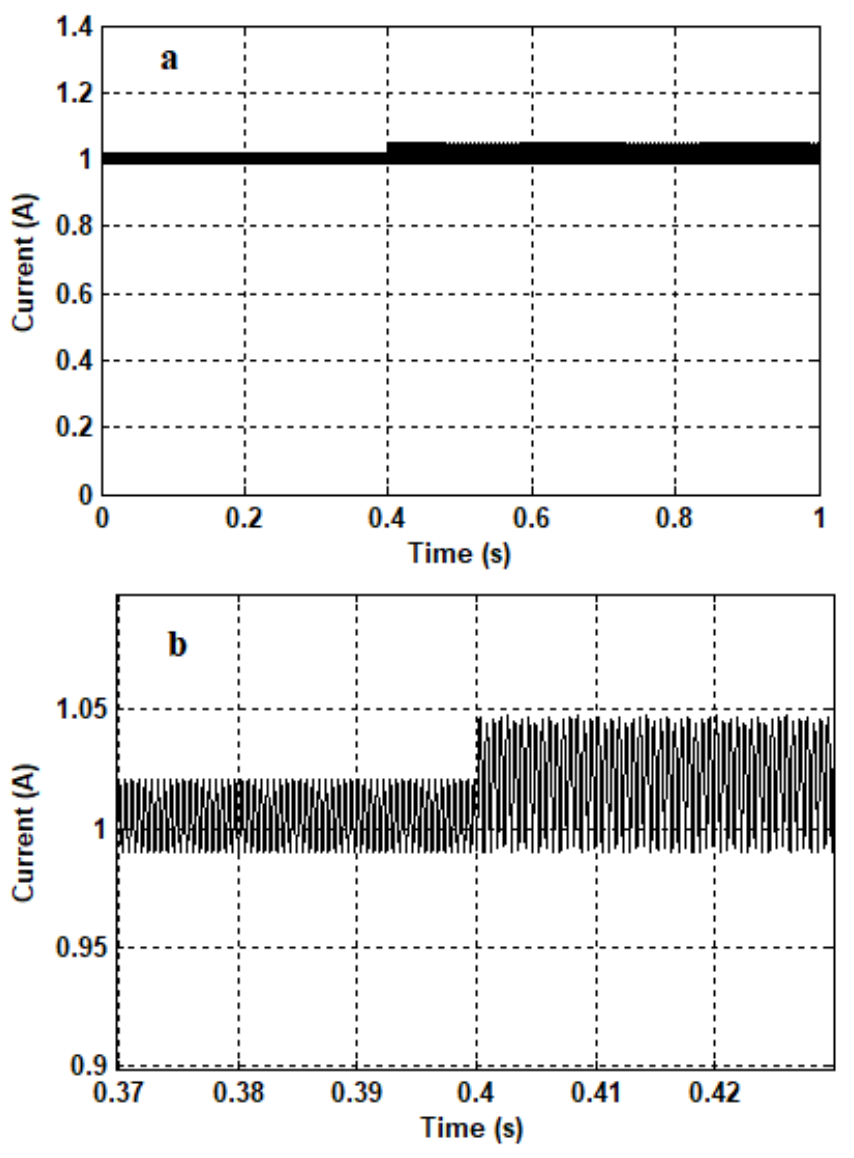

Fig. 9. (a) Simulation results of the Output load current response with an input voltage variation. (b) Zoom in.
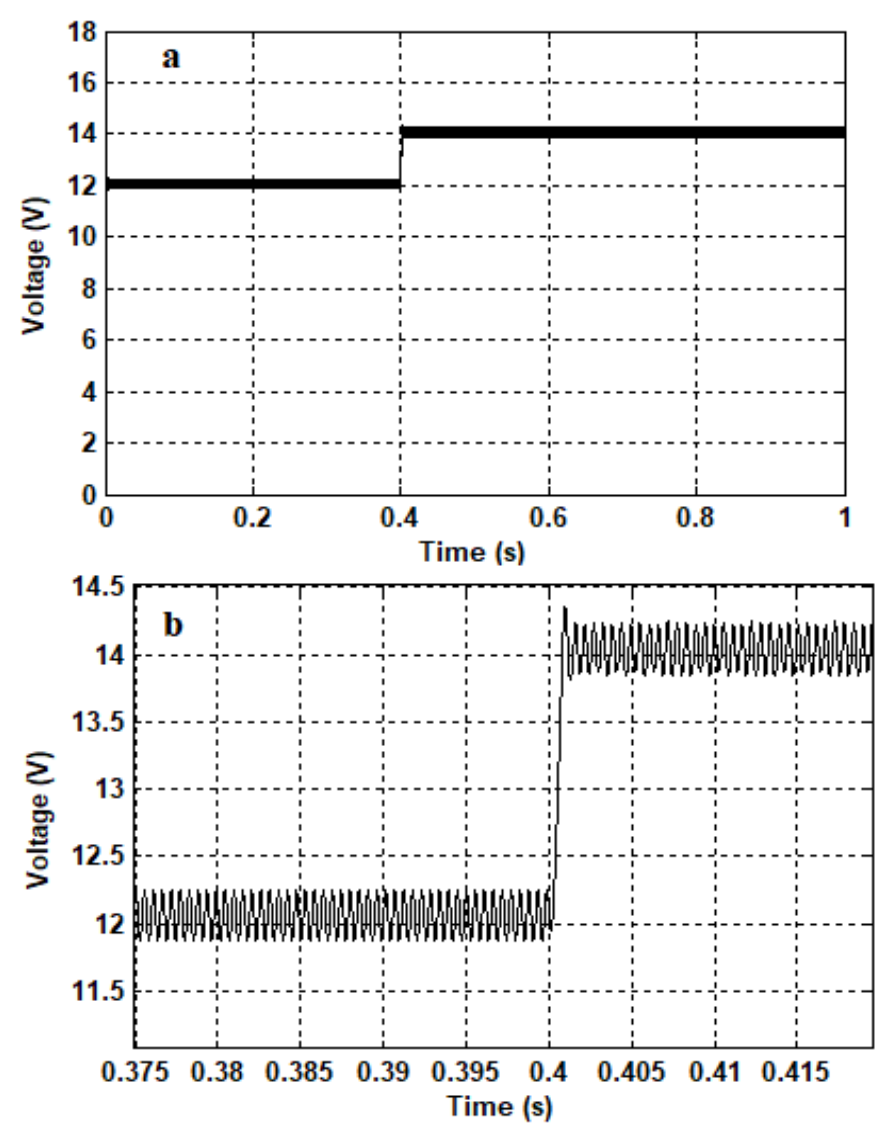

Fig. 10. (a) Simulation results of the Output voltage response with an reference voltage variation. (b) Zoom in.
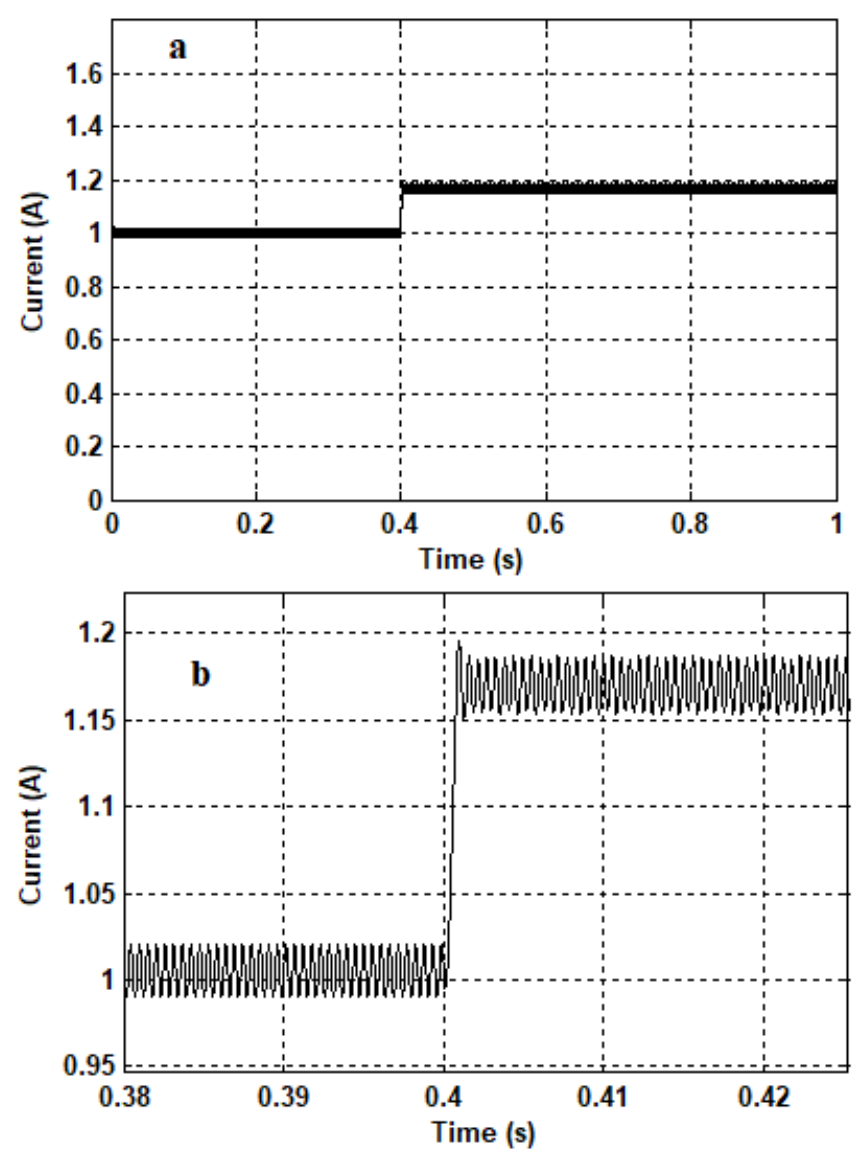

Fig. 11. (a) Simulation results of the Output load current response with a reference voltage variation. (b) Zoom in.

\section{CONCLUSION}

The HM-based SM controller has improved the dynamic behavior and it is able to cope with input voltage and load variations, as well as provide stability in any operating conditions.

The carried-out simulations show very promising results in terms of reference tracking performances and robustness. They prove the appropriateness of sliding mode control for such kind of system.

\section{REFERENCES}

[1] Ben Said S, et al., HIL simulation approach for a multicellular converter controlled by sliding mode, International Journal of Hydrogen Energy (2017).

[2] Cucuzzella, M., Lazzari, R., Trip, S., Rosti, S., Sandroni, C., \& Ferrara, A. (2018). Sliding mode voltage control of boost converters in DC microgrids. Control Engineering Practice, 73, 161-170.

[3] A. Hadri Hamida, A. Ghoggal, Fatiha Khelili and S. Zerouali, "Étude qualitative des convertisseurs multicellulaires entrelacés par la théorie de bifurcation", Proc. Conf. SGE 2018, Nancy, France, (2018).

[4] A. Hadri Hamida, A. Ghoggal, Fatiha Khelili and S. Zerouali, SecondOrder Sliding Mode Control Scheme with a Non-Linear Phenomenon Analysis of a DC-DC Power Converter Dedicated to Distributed Power Systems", International Conference on Electronics, Energy and Measurement, Algiers, (2018)

[5] Al-Hammouri AT, Nordstrom L, Chemine M, Vanfretti L, Honeth N, Leelaruji R. Virtualization of synchronized phasor measurement units within real-time simulators for smart grid applications. In: Power and Energy society general meeting. IEEE; 2012. P. 1-7.

[6] Thierry. Meynard, Analysis and Design of Multicell DC/DC Converters using Vectorized Models, ISTE Ltd and John Wiley \& Sons, Inc. (2015) 
[7] V. Utkin, J. Guldner, and J. X. Shi, Sliding Mode Control in Electromechanical Systems. London, UK: Taylor and Francis, 1999

[8] Yin, Y. Liu, J. Vazquez, S. Wu, L. Franquelo, Leopoldo.G. Disturbance observer based second order sliding mode control for DCDC buck converters. IEEE Industrial Electronics Society, 43rd Annual Conference. (2017)

[9] A. Hadri Hamida, A. Ghoggal, Fatiha Khelili and S. Zerouali, SecondOrder Sliding Mode Control Scheme with a Non-Linear Phenomenon Analysis of a DC-DC Power Converter Dedicated to Distributed Power Systems", International Conference on Electronics, Energy and Measurement, Algiers, (2018)

[10] Hoon Leea, Vadim I. Utkinb and Andrey Malininc. Chattering reduction using multiphase sliding mode control, International Journal of Control Vol. 82, No. 9, (2009), 1720-1737

[11] Aroudi, A., Robert, B., and Leyva, R. (2005), 'Sliding Mode Control of a High Voltage DC-DC Buck Converter in Circuit Theory and Design, Proceedings of the 2005 European Conference (Vol. 3,28), Cork, Ireland, pp. III/55-III/59.

[12] Lee, H., and Utkin, V.I. (2006), 'The Chattering Analysis', in Advances in Variable Structure and Sliding Mode Control, Lecture Notes in Control and Information Sciences, eds. C. Edwards, E. Fossas Colet, \& L. Fridman, Berlin: Springer.

[13] Daniel González Montoya; Carlos Andrés Ramos-Paja; Roberto Giral. Improved Design of Sliding-Mode Controllers Based on the Requirements of MPPT Techniques, IEEE Transactions on Power Electronics, (2016)

[14] Mahdi Salimi, Jafar Soltani, Adel Zakipour, Navid Reza Abjadi. Hyper-plane sliding mode control of the DC-DC buck/boost converter in continuous and discontinuous conduction modes of operation, IET Power Electron., pp. 1-10, (2015)

[15] Junxiao Wang; Shihua Li; Jun Yang; Bin Wu; Qi Li. Extended state observer-based sliding mode control for PWM-based DC-DC buck power converter systems with mismatched disturbances, IET Control Theory \& Applications (2015).

[16] Zhao, Yue; Qiao, Wei; and Ha, Daihyun, "A Sliding-Mode Duty-Ratio Controller for DC/DC Buck Converters with Constant Power Loads" (2014).

[17] Oswaldo López-Santos, Luis Martínez-Salamero, Germain García1 Hugo Valderrama-Blavi3, Daniel O. Mercuri. Efficiency analysis of a sliding-mode controlled quadratic boost converter, IET Power Electron, Vol. 6, Iss. 2, pp. 364-373, (2013]

[18] S. Tan, Y. Lai, C. Tse. Sliding Mode Control of Switching Power Converters. CRC Press, (2011)

[19] J.F. Tsai, Y.P. Chen. Sliding mode control and stability analysis of buck DC-DC converter. International Journal of Electronics. 94 (2007).

[20] L. Martinez-Salamero, A. Cid-Pastor, A. El Aroudi, R. Giral, J. Calvente, and G. Ruiz-Magaz. Sliding-Mode Control of DC-DC Switching Converters, Proceedings of the 18th World Congress. The International Federation of Automatic Control Milano (Italy) August 28 - September 2, (2011)

[21] Ben Said, Ben Saad K, Benrejeb M. Sliding mode control for multicell converters. In: International conference on control, engineering and information technology, vol.2, pp39-44 (2013) 